\title{
Relationship of irrigated wheat yield with temperature in hot environments of Sudan
}

\author{
Abuelgasim I. I. Musa ${ }^{1,2}\left(\right.$ D $\cdot$ Mitsuru Tsubo ${ }^{3} \cdot$ Imad-Eldin A. Ali-Babiker $^{4} \cdot$ Toshichika lizumi $^{5} \cdot$ Yasunori Kurosaki $^{3}$. \\ Yasuomi Ibaraki $^{6} \cdot$ Faisal M. A. El-Hag ${ }^{3,4} \cdot$ Izzat S. A. Tahir $^{4} \cdot$ Hisashi Tsujimoto $^{3}$
}

Received: 24 October 2020 / Accepted: 8 June 2021 / Published online: 18 June 2021

(c) The Author(s) 2021

\begin{abstract}
A negative effect of increasing temperature on wheat production in the coming decades has been projected for Sudan, which is a major wheat producer in Sub-Saharan Africa. Wheat is susceptible to high temperature, so trend analysis of historical yields together with observed temperature is critical for understanding the effect of climate change. The objective of this study was to determine the association between yield of irrigated wheat in hot drylands of Sudan and temperature during the growing season (November-February). Regional-scale yield data in three major wheat-producing areas (Northern State, Gezira State, and Kassala State) in 48 crop seasons (1970/71-2017/18) were used to determine the correlation of yield with maximum (TMAX) and minimum temperatures (TMIN) at representative meteorological stations (Dongola, Wad Medani, and New Halfa, respectively). Frequencies of days with maximum temperature above $35^{\circ} \mathrm{C}$ (THD) and minimum temperature above $20^{\circ} \mathrm{C}$ (THN) were also used for correlation analysis. In all three areas, regression analysis detected upward trends in the growing-season temperature. The increase in temperature was particularly evident at Dongola, although no such trend has been reported previously. The yields were negatively correlated with the growing-season temperature, particularly THN in Northern State, TMAX in Gezira State, and TMIN in Kassala State. These results confirm that the recent increase in the growing-season temperature might have reduced the yield to some extent in the breadbasket of Sudan.
\end{abstract}

\section{Introduction}

Recent climate change has been reducing crop production in many parts of the world including Africa (IPCC 2014, 2019). Temperature tends to increase over Sub-Saharan Africa (Gil-Alana et al. 2019), and increasing trends in maximum and minimum temperatures are most likely associated with increasing trends in warm days and nights (Omondi et al. 2014; Ongoma and Chen 2017; Gebrechorkos et al.

Abuelgasim I. I. Musa

gasim1_78@yahoo.com

1 United Graduate School of Agricultural Science, Tottori University, Tottori, Japan

2 Sudan Meteorological Authority, Khartoum, Sudan

3 Arid Land Research Center, Tottori University, Tottori, Japan

4 Agricultural Research Corporation, Khartoum, Sudan

5 Institute for Agro-Environmental Sciences, National Agriculture and Food Research Organization, Tsukuba, Japan

6 Faculty of Agriculture, Yamaguchi University, Yamaguchi, Japan
2019) in both arid and tropical regions (Elagib 2010; Mengistu et al. 2014; Nsubuga et al. 2014). In countries vulnerable to climate change, temperature increases would impact field crop production (Hatfield et al. 2011; Hatfield and Prueger 2015), particularly that of wheat, a major cereal that is normally grown under cool climate. The first step toward wheat adaptation is to understand the historic relationship between crop productivity and temperature variability (Iizumi et al. 2018; Ray et al. 2019).

Case studies on wheat yield trends and temperature variations have been reported from various countries (You et al. 2009; Brisson et al. 2010; Licker et al. 2013; Tack et al. 2015; Asseng et al. 2017; Morgounov et al. 2018). Yield loss of winter wheat in Kansas (USA) in 1985-2013 largely resulted from freezing temperatures in fall and extreme heat in spring during the growing season from September to May (Tack et al. 2015). In China, wheat yield decreased by $4.5 \%$ in 1979-2000 (You et al. 2009). Under rainfed conditions, an 11\% yield decline in 1973-2010 was reported in Picardy (France), a vital winter wheat-producing region in Europe, where maximum spring temperatures increased by $2.4{ }^{\circ} \mathrm{C}$ and total fall precipitation decreased by $9 \%$ over the study 
period (Licker et al. 2013). Rainfed spring wheat in Eurasia and North America is harmed by high temperature in June and July, when heading, flowering, and ripening occur (Morgounov et al. 2018). In regions where spring wheat is grown under irrigation, such as India, higher mean growingseason temperature is associated with lower yield (Asseng et al. 2017). According to model simulation at a global scale (Asseng et al. 2015), wheat production would fall by $6 \%$ for each degree of temperature increase.

Wheat production is considerably reduced by temperatures above the optimum. According to Porter and Gawith (1999), the optimum temperature for wheat is around $20^{\circ} \mathrm{C}$, ranging between $17^{\circ} \mathrm{C}$ and $23^{\circ} \mathrm{C}$; plants stop to grow below $0{ }^{\circ} \mathrm{C}$ or above $37^{\circ} \mathrm{C}$, and die at around $-17^{\circ} \mathrm{C}$ or $47.5^{\circ} \mathrm{C}$. Increased daytime and nighttime temperatures decrease wheat yields in controlled environments (Prasad et al. 2008; García et al. 2015, 2016; Narayanan et al. 2015; Nuttall et al. 2018). The exposure of wheat plants to daytime temperatures $\geq 35^{\circ} \mathrm{C}$ during anthesis decreases grain yield (Nuttall et al. 2018), and additional exposure to high nighttime temperature further decreases it (Narayanan et al. 2015). Nighttime temperature $\geq 20^{\circ} \mathrm{C}$ from booting to maturity shortens the duration of grain filling, hence reducing yield (Prasad et al. 2008). Similar responses to high night temperature have been found under field conditions from stem elongation to anthesis (García et al. 2015) and from post-anthesis to maturity (García et al. 2016). High temperature during grain filling decreases yield in wheat-producing regions with a hot climate such as Sudan (Ishag and Mohamed 1996).

The effect of climate change is particularly severe in SubSaharan Africa, and the Sudano-Sahelian countries could experience a considerable loss of agricultural production (Calzadilla et al. 2013). Sudan is one of the most important irrigated wheat producers in the region; its climate is characterized by high temperature and low humidity (Negassa et al. 2013). Wheat production in this hot region will deteriorate in the future (Asseng et al. 2017), and heat-resistant cultivars need to be improved to meet the future demand in the country. The only study (Adam and Ageeb 1994) that reported on the relationship between wheat yields and temperature in Sudan analyzed a single area, the Gezira Scheme, during a short period (10 crop seasons from 1981/82 to 1991/92).

Although wheat yields in Sudan are low due to a combination of constraints such as high temperature, short growing season, low fertilizer input, and low soil carbon content, we focus on temperature in this study. The main objective of this study was to investigate the regional-scale relationship of wheat yields with temperature in Sudan for the last five decades. The specific objectives were to (1) evaluate recent trends in annual temperature, (2) analyze time series trends in temperature during the wheat growing season, and (3) determine how yield is associated with growing-season temperature. We also discussed the future trends in the effect of climate change on yields. To the best of our knowledge, this is the first study to investigate the yield-temperature relationship in Sudan using long-term observed data.

\section{Methods}

\subsection{Study area}

Three major wheat-producing areas in Sudan were selected: Northern State (northern region), Gezira State (central region), and Kassala State (eastern region) (Fig. 1). They cover about $80 \%$ of the wheat cultivation area and account for about $85 \%$ of domestic production (FAO 2019). Springtype wheat is cultivated under irrigated conditions in the relatively cold, dry season. Irrigated fields are located along the Nile River in Northern State, the Blue Nile River in

\section{Irrigated areas}

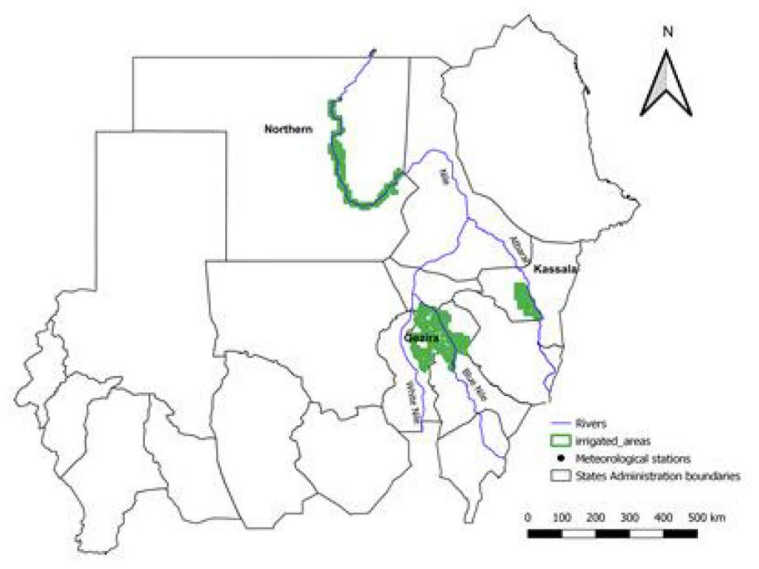

Elevation

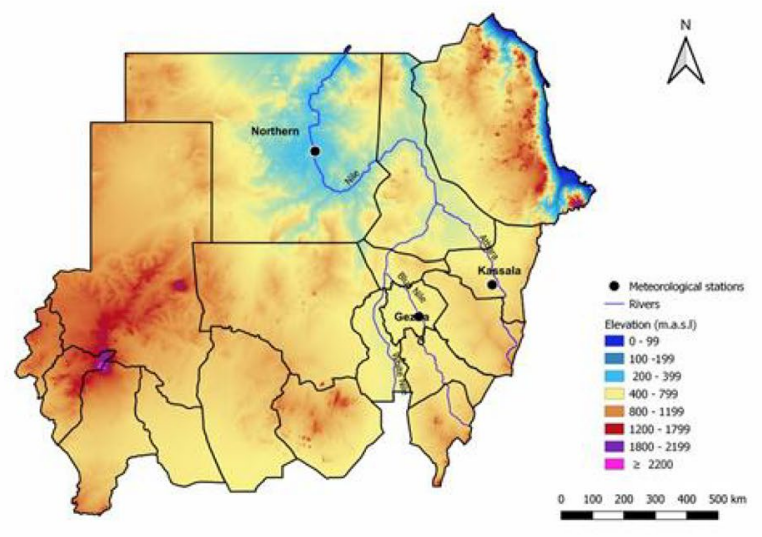

Fig. 1 Three major wheat-producing (irrigated) areas of Sudan (Northern State, Gezira State, and Kassala State) and their representative meteorological stations (Dongola, Wad Medani, and New Halfa, respectively) 
Gezira State on the central clay plain, and the Atbara River in Kassala State.

Data from three meteorological stations were used: Dongola $\left(19.17^{\circ} \mathrm{N}, 30.48^{\circ} \mathrm{E}\right)$ in Northern State, Wad Medani $\left(14.40^{\circ} \mathrm{N}, 33.48^{\circ} \mathrm{E}\right)$ in Gezira State, and New Halfa $\left(15.32^{\circ} \mathrm{N}, 35.60^{\circ} \mathrm{E}\right)$ in Kassala State (Fig. 1). They lie on flat land (elevations a.s.l.: Dongola, $226 \mathrm{~m}$; Wad Medani, $408 \mathrm{~m}$; and New Halfa, $462 \mathrm{~m}$ ) and are representative of the study areas. Dongola is located in a hyper-arid region with an annual rainfall of $<15 \mathrm{~mm}$ and an annual potential evapotranspiration (PET) of about $2300 \mathrm{~mm}$. Wad Medani and New Halfa are located in arid regions with an annual rainfall of 250-300 mm and an annual PET of 1950-2250 mm (Elagib and Mansell 2000). According to the FAO (2012) soil classification, Arenosols, Fluvisols, Leptosols, and Vertisols are found in Northern State; mainly Vertisols and, in small areas, Luvisols in Gezira State; and Luvisols, Cambisols, and Vertisols in Kassala State.

\subsection{Data collection and processing}

Wheat crop data of the study areas were obtained from the Ministry of Agriculture and Natural Resources of Sudan. The time series data of wheat production $(\mathrm{kg})$ and harvested area (ha) for 48 years (1970/71-2017/18 crop seasons) were used. The year-by-year grain yields $\left(\mathrm{kg} \mathrm{ha}^{-1}\right)$ were calculated as the production divided by the harvested area. No data were available for Gezira and Kassala states in 1984/85 and for Kassala State in 2006/07, 2008/09, and 2009/10. The regional-scale yield shows a reasonable agreement with the plot-scale yield at research stations and if the two types of yield are compared for the overlapped period (2015/16 and 2016/17); the yields of the major varieties, i.e., Imam, Debeira, Wad Elneel, and Zakia, in 2015/16 and 2016/17 range between 1800 and $6100 \mathrm{~kg} \mathrm{ha}^{-1}$ at Gezira Research Station and between 1300 and $4500 \mathrm{~kg} \mathrm{ha}^{-1}$ at New Halfa Research Station (Tahir et al. 2018).

Daily maximum and minimum temperature data at the three meteorological stations for 1970-2018 were obtained from the Sudan Meteorological Authority. Prior to the data processing, the homogeneity test of the temperature time series data was conducted to detect the changepoints using RHtestsV4, software developed by the Joint $\mathrm{CCl} / \mathrm{Clivar} /$ JCOMM Expert Team on Climate Change Detection and Indices (Wang and Feng 2013); detected changepoints of the minimum temperature time series data at Wad Medani and New Halfa were adjusted using a provision of QuantileMatching (QM) included in the software.

Annual and monthly averages of daily maximum temperature (annual and monthly TMAX, respectively) and daily minimum temperature (annual and monthly TMIN, respectively) were calculated. Also, extreme temperature indicators of hot days (maximum temperature $>35^{\circ} \mathrm{C}$ ) and hot nights (minimum temperature $>20^{\circ} \mathrm{C}$ ) (Collins et al. 2000) were used. The ratio of hot days to the number of days in a month (monthly THD) and the ratio of hot nights to the number of days in a month (monthly THN) were calculated using ClimPACT2, software introduced by the Commission for Climatology Expert Team on Sector-specific Climate Indices of the World Meteorological Organization. In Sudan, wheat is typically planted in November, heading and flowering occur in January, and the ripening period is mainly February; November-February was defined as the growing season in this study. Means of daily maximum and minimum temperatures for the 4 months (growing-season TMAX and TMIN, respectively) and the ratios of hot days and hot nights to the number of days in the 4 months (growing-season THD and THN, respectively) were calculated.

\subsection{Data analysis}

To determine the trends of the temperature indicators (TMAX, TMIN, THD, and THN), linear regression analysis over time was carried out. To determine whether a time series had a monotonic upward or downward direction, the temperature indicators were further tested using the nonparametric Mann-Kendall and Sen's slope estimator tests. The trend lines from regression analysis were used to analyze the yield-temperature relationship.

Increasing yield trends could be expected owing to newly released cultivars, increased use of quality seeds, increased inorganic fertilizer application, and better irrigation and technology dissemination (Faki and Ismail 1994; Tahir et al. 2000, 2020a). A detrending approach (Nicholls 1997) was used to remove the effect of agricultural development: time series data of the yields were detrended as deviations (anomalies) from regression lines detected at a significance level of 5\%. All the temperature indicators with significant trends were detrended using the regression lines; in the absence of a trend, anomalies from the means over the period were used. The relationships between the detrended yields and temperature indicators were analyzed by correlating the anomalies using Pearson's correlation and nonparametric Spearman's rank correlation. Prior to the correlation analyses, the Shapiro-Wilk normality test was conducted to detect whether the yield anomalies were normally distributed and therefore the detrended procedure functioned validly; all the datasets met the assumption of normality at $\mathrm{p} \leq 0.05$.

Counterfactual yield is the estimated yield what would occur without warning and derived by inputting detrended temperature data to the established yield-temperature relationships. To calculate the counterfactual yields, (i) 5-year moving averages of the original yields and growing-season mean temperatures (growing-season averages of daily mean temperature $=$ average of daily TMAX and TMIN) were calculated; (ii) temperature increments relative to $1970 / 71$ 
over the period were calculated using linear equations, with which the 5-year moving averages were fitted; (iii) yield changes relative to $1970 / 71$ were calculated by substituting the temperature increments into equations of linear regression between the anomalies of growing-season mean temperatures and the original yields from the 5-year moving averages; and (iv) yield changes were subtracted from the original yield. This approach is essentially similar to the methods used in the previous studies (Lobell and Field 2007; Lobell et al. 2011; Moore and Lobell 2015). All data analyses were conducted in MS Excel, SPSS v. 25, and R v. 3.6.1 software.

\section{Results}

\subsection{Maximum and minimum temperatures}

Annual TMIN and TMAX trends for 1970-2018 at the three meteorological stations are shown in Fig. 2. Annual
TMIN had increasing trends $(p \leq 0.05)$; slopes of the regression lines indicated a higher increase per decade at Dongola $\left(0.83{ }^{\circ} \mathrm{C}\right)$ than at Wad Medani $\left(0.50{ }^{\circ} \mathrm{C}\right)$ and New Halfa $\left(0.31^{\circ} \mathrm{C}\right)$. Annual TMAX had increasing trends at Dongola $\left(0.23{ }^{\circ} \mathrm{C}\right)$ and Wad Medani $\left(0.25{ }^{\circ} \mathrm{C}\right)(p \leq 0.05)$, but not at New Halfa. The Mann-Kendall and Sen's slope estimator tests also detected monotonic upward trends in both TMAX and TMIN at all locations $(p \leq 0.05)$, except for TMAX at New Halfa.

The highest daily TMAX during the study period was $49.8^{\circ} \mathrm{C}$ at Dongola on 24 June $2010,47.4{ }^{\circ} \mathrm{C}$ at Wad Medani on 27 May 1991 , and $47.5^{\circ} \mathrm{C}$ at New Halfa on 25 May 1998. The lowest daily TMAX was $16.2^{\circ} \mathrm{C}$ at Dongola on 29 January $1983,20.3^{\circ} \mathrm{C}$ at Wad Medani on 26 December 1992, and $20.5^{\circ} \mathrm{C}$ at New Halfa on 10 January 1990. The highest daily TMIN was $35.0^{\circ} \mathrm{C}$ at Dongola on 18 May $2016,32.6{ }^{\circ} \mathrm{C}$ at Wad Medani on 7 May 2009 , and $34.7^{\circ} \mathrm{C}$ at New Halfa on 30 April 2011. The lowest daily TMIN was $1.0^{\circ} \mathrm{C}$ at Dongola on 9 February $1982,4.1^{\circ} \mathrm{C}$ at Wad
Fig. 2 Linear trends in annual average daily maximum (TMAX) and minimum temperatures (TMIN) from 1970 to 2018 at the Dongola, Wad Medani, and New Halfa meteorological stations in Sudan. Linear lines (estimated by least squares regression) in the figures are significant increasing trends in TMAX and TMIN
TMAX
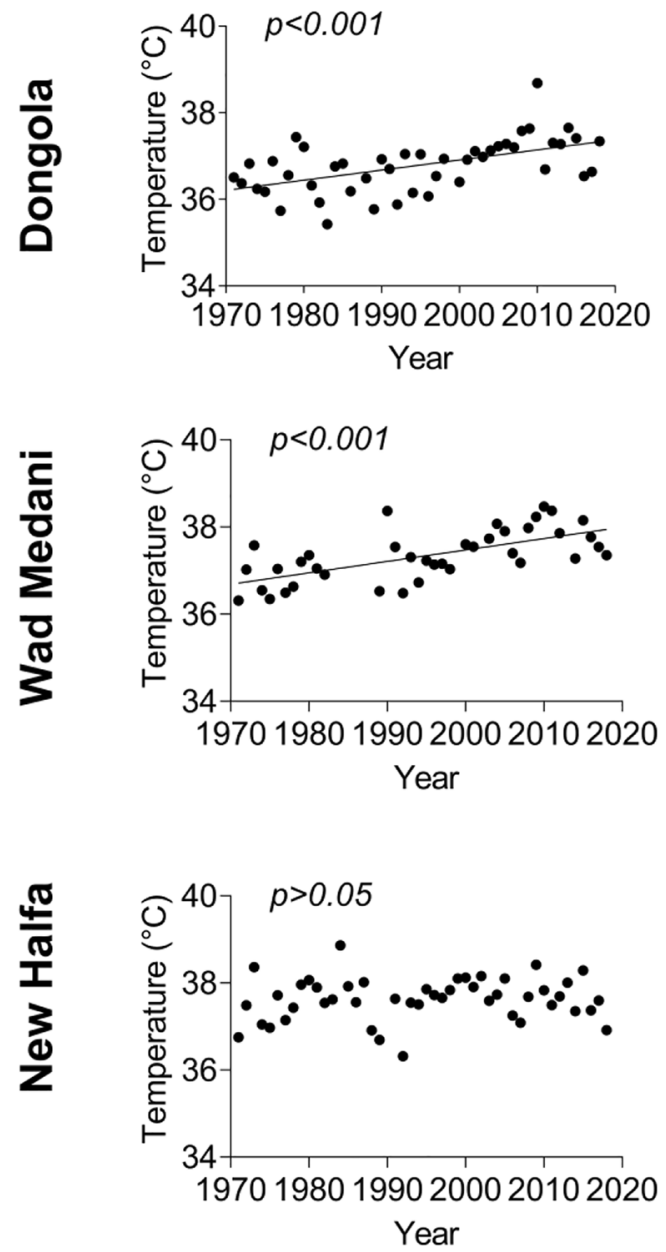

\section{TMIN}
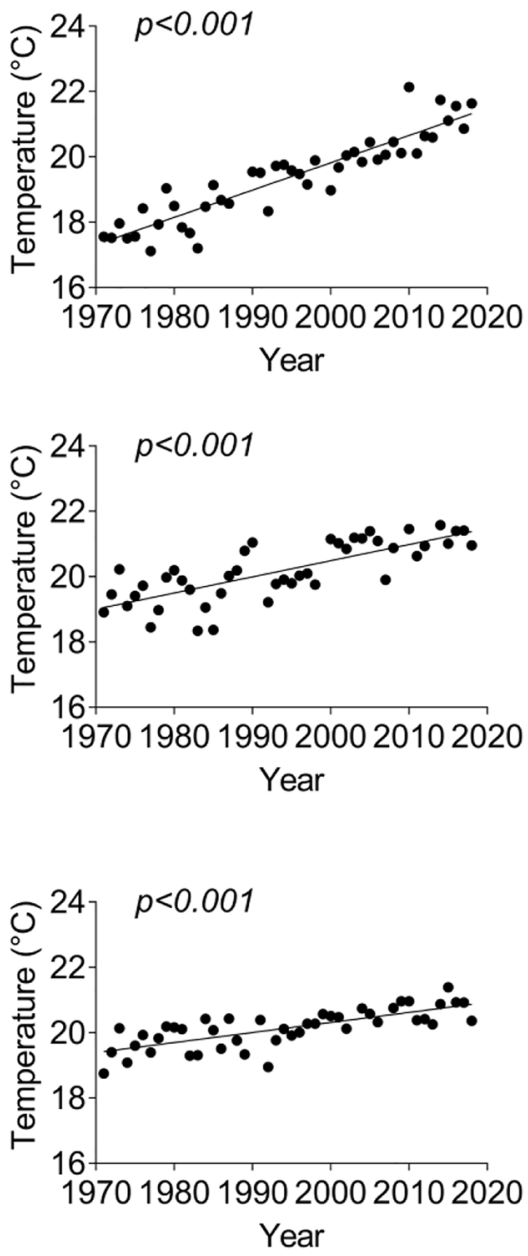
Medani on 25 December 1971 , and $4.8^{\circ} \mathrm{C}$ at New Halfa on 6 February 1983.

\subsection{Growing-season temperature indicators}

The distribution of monthly TMAX and TMIN is shown in Fig. 3. Among the median values at Dongola, the highest TMAX was in June and the highest TMIN was in August. At Wad Medani and New Halfa, the highest TMAX was in May and the highest TMIN in June. All locations had the lowest monthly TMAX and TMIN (medians) in January, followed by December and February. Linear regression analysis (data not shown) revealed monthly TMAX and TMIN trends for the growing season. Dongola had increasing trends in TMIN in all months $(p \leq 0.05)$ and in TMAX in November only $(p \leq 0.05)$. Wad Medani had a monthly TMAX increase over the entire period $(p \leq 0.05)$ except January, and increasing trends in TMIN in December, January, and February. New Halfa had increasing trends in TMIN over the entire period $(p \leq 0.05)$ except January and no trends in TMAX. In the Mann-Kendall and Sen's slope estimator tests (Table 1), Dongola had the same results for TMIN, but a monotonic upward trend in TMAX in December instead of November. Wad Medani had monotonic upward trends in TMAX in November and December but not in January or February, and increasing trends in TMIN in all months except January. New Halfa had the same results (no trends) for TMAX, but monotonic upward trends for TMIN over the entire period $(p \leq 0.05)$.

Linear trends in the growing-season TMAX and TMIN are shown in Fig. 4. All three locations had increasing trends in both TMAX (decadal increase of $0.26{ }^{\circ} \mathrm{C}$, $0.37{ }^{\circ} \mathrm{C}$, and $0.20^{\circ} \mathrm{C}$ for Dongola, Wad Medani, and New Halfa, respectively) and TMIN $\left(0.71{ }^{\circ} \mathrm{C}, 0.40^{\circ} \mathrm{C}\right.$, and $0.40^{\circ} \mathrm{C}$ ) (all $p \leq 0.05$ ). In the nonparametric tests, both TMAX and TMIN had monotonic upward trends at all three locations, except for TMAX at Dongola (Table 1).
Fig. 3 Box-and-whisker plots of monthly average daily maximum (TMAX) and minimum temperatures (TMIN) for from 1970 to 2018 at the Dongola, Wad Medani, and New Halfa meteorological stations in Sudan. Each box indicates the lower and upper quartiles, the horizontal line in the box represents the median, and the whiskers (vertical lines) denote the minimum and maximum values, excluding outliers (circles)

\section{TMAX}
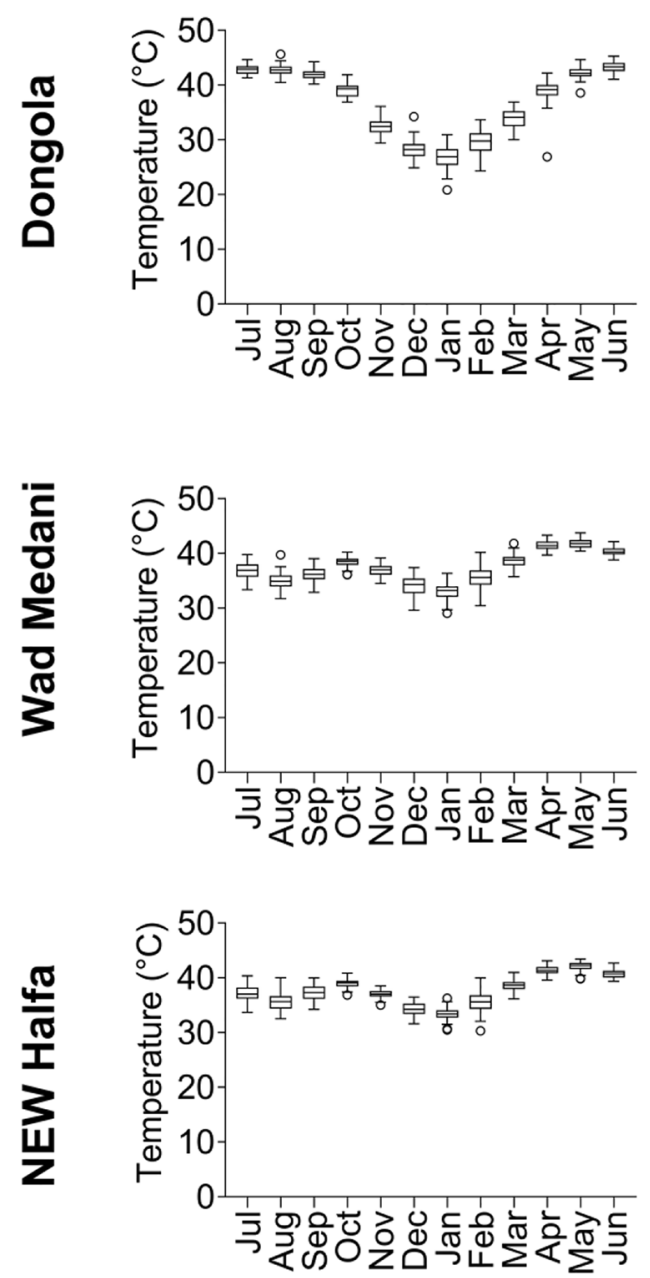

\section{TMIN}
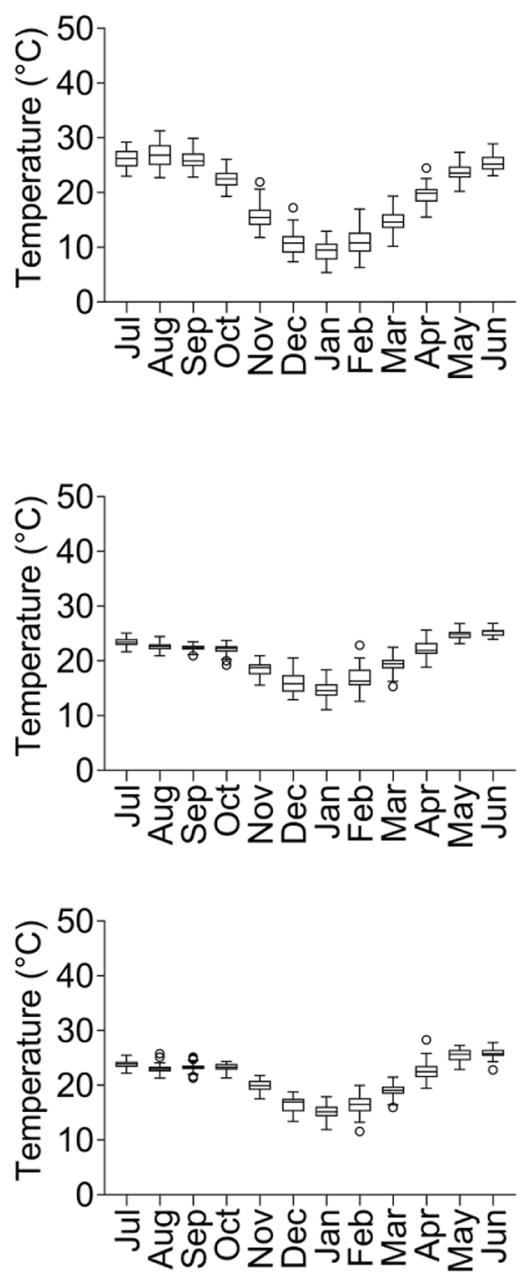
Table 1 Mann-Kendall ( $Z$ statistic) and Sen's estimator tests for monthly temperature indicators during wheat growing season in 1970-2018 at 3 meteorological stations in Sudan

Fig. 4 Wheat growing-season (November-February) average daily maximum (TMAX) and minimum temperatures (TMIN) from 1970 to 2018 at the Dongola, Wad Medani, and New Halfa meteorological stations in Sudan. Linear lines (estimated by least squares regression) in the figures are significant increasing trends in TMAX and TMIN

\begin{tabular}{|c|c|c|c|c|c|c|c|c|c|c|c|}
\hline \multirow[t]{2}{*}{ Station } & \multirow{2}{*}{$\begin{array}{l}\text { Tem- } \\
\text { perature } \\
\text { indicator }\end{array}$} & \multicolumn{2}{|c|}{ November } & \multicolumn{2}{|c|}{ December } & \multicolumn{2}{|c|}{ January } & \multicolumn{2}{|c|}{ February } & \multicolumn{2}{|c|}{ Season } \\
\hline & & $Z$ & $p$-value & $Z$ & $p$-value & $Z$ & $p$-value & $Z$ & $p$-value & $Z$ & $p$-value \\
\hline \multirow[t]{4}{*}{ Dongola } & TMAX & 1.82 & 0.07 & 2.47 & 0.01 & 0.86 & 0.39 & 1.25 & 0.20 & 1.87 & 0.06 \\
\hline & TMIN & 4.78 & $<0.01$ & 4.50 & $<0.01$ & 3.39 & $<0.01$ & 3.75 & $<0.01$ & 5.15 & $<0.01$ \\
\hline & THD & 2.02 & 0.04 & 1.23 & 0.21 & 0.67 & 0.50 & 1.06 & 0.28 & 2.21 & 0.02 \\
\hline & THN & 2.29 & 0.02 & 1.96 & 0.04 & 0.46 & 0.60 & 1.51 & 0.12 & 2.52 & 0.01 \\
\hline \multirow[t]{4}{*}{ Wad Medani } & TMAX & 2.57 & 0.01 & 2.89 & $<0.01$ & 1.56 & 0.11 & 1.84 & 0.06 & 3.43 & $<0.01$ \\
\hline & TMIN & 2.97 & 0.02 & 1.44 & $<0.01$ & 1.50 & 0.13 & 2.59 & $<0.01$ & 3.43 & $<0.01$ \\
\hline & THD & 1.18 & 0.23 & 4.99 & $<0.01$ & 2.11 & 0.03 & 2.08 & 0.03 & 3.17 & $<0.01$ \\
\hline & THN & 1.46 & 0.14 & 1.54 & 0.12 & 0.83 & 0.40 & 1.58 & 0.11 & 2.38 & 0.01 \\
\hline \multirow[t]{4}{*}{ New Halfa } & TMAX & 1.30 & 0.19 & 1.53 & 0.12 & 1.07 & 0.20 & 1.48 & 0.13 & 2.57 & 0.01 \\
\hline & TMIN & 2.95 & $<0.01$ & 2.52 & 0.01 & 2.22 & 0.02 & 3.11 & $<0.01$ & 3.41 & $<0.01$ \\
\hline & THD & -0.23 & 0.81 & 1.28 & 0.20 & 0.8 & 0.40 & 1.31 & 0.18 & 2.04 & 0.04 \\
\hline & THN & 2.38 & 0.01 & 1.31 & 0.18 & 0.59 & 0.55 & 1.82 & 0.06 & 3.06 & $<0.01$ \\
\hline
\end{tabular}

TMAX, maximum temperature; TMIN, minimum temperature; THD, proportion of hot days in a month; $T H N$, proportion of hot nights in a month

TMAX
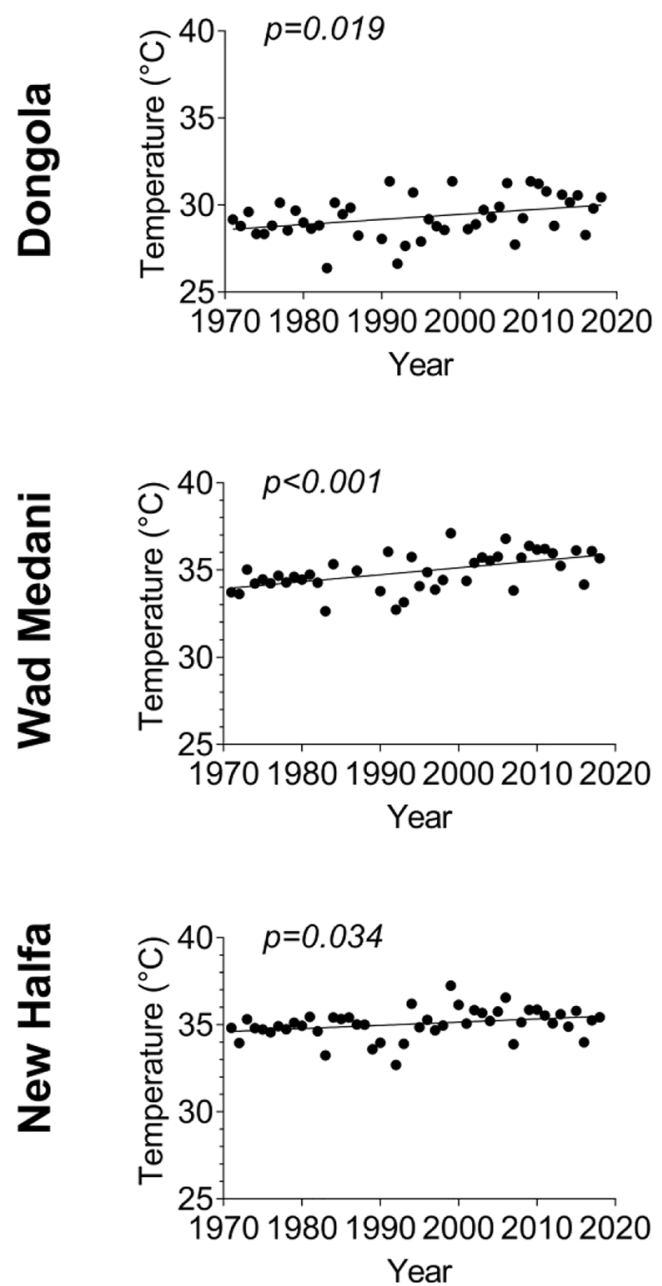

TMIN
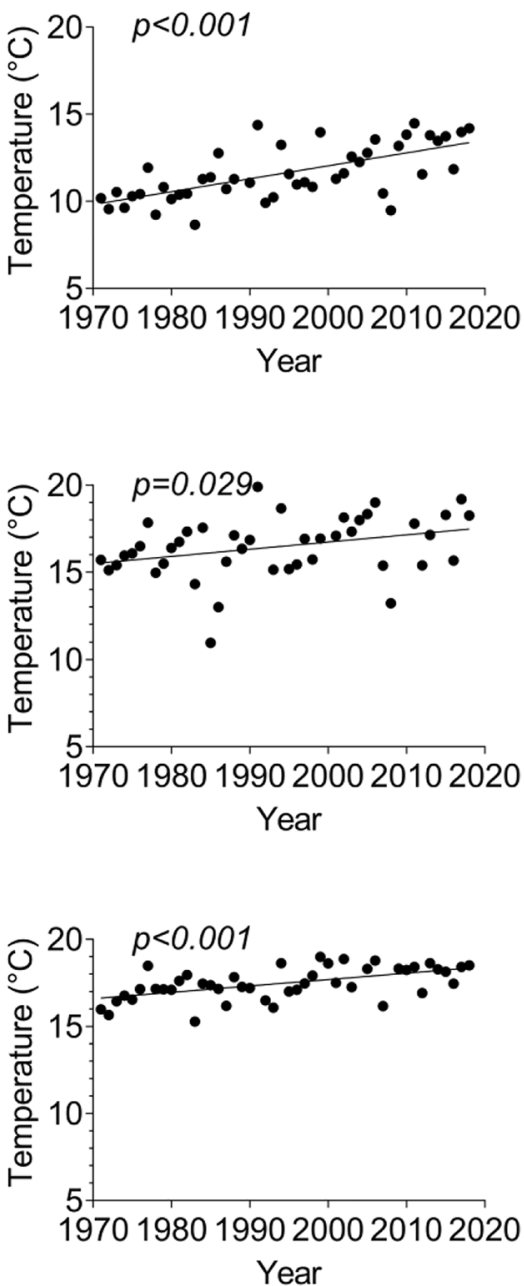
During the growing season, the highest daily TMAX recorded at Dongola was higher in November $\left(41.5^{\circ} \mathrm{C}\right)$ and February $\left(42.4{ }^{\circ} \mathrm{C}\right)$ than in December $\left(37.6{ }^{\circ} \mathrm{C}\right)$ and January $\left(39.0^{\circ} \mathrm{C}\right)$. In contrast, the highest daily TMIN was higher in December $\left(34.0^{\circ} \mathrm{C}\right)$ and January $\left(33.5^{\circ} \mathrm{C}\right)$ than in November $\left(26.0^{\circ} \mathrm{C}\right)$ and February $\left(24.0^{\circ} \mathrm{C}\right)$. At both Wad Medani and New Halfa, the highest daily TMAX was above $40{ }^{\circ} \mathrm{C}$ and TMIN was above $26^{\circ} \mathrm{C}$ in November-February. All records were higher than the thresholds $\left(35^{\circ} \mathrm{C}\right.$ for hot days and $20^{\circ} \mathrm{C}$ for hot nights).

In Dongola, monthly THN had increasing trends in November and December $(p \leq 0.05)$ in both the linear regression and nonparametric analyses and THD had a monotonic upward trend in November (Table 1). In Wad Medani, monthly THD had upward trends $(p \leq 0.05)$ except in November in both the linear regression and nonparametric analyses, and monthly THN had an increasing trend in February $(p \leq 0.05)$ in linear regression analysis but no trend in nonparametric tests (Table 1). In New Halfa, THN had an increasing trend in November in both the linear regression and nonparametric analyses (Table 1$)(p \leq 0.05)$ and in
February in linear regression analysis $(p \leq 0.05)$. Growingseason THD and THN had increasing trends at all three locations ( $p \leq 0.05)$, except for THD at New Halfa, whereas nonparametric analysis detected monotonic upward trends in all cases (Table 1).

\subsection{Relationships between yields and growing-season temperature indicators}

The yield trends for the study period are shown in Fig. 5. All study areas had increasing trends $(p \leq 0.05)$. Kassala State had the highest increase rate $\left(23 \mathrm{~kg} \mathrm{ha}^{-1}\right.$ per year), followed by Gezira State $\left(21 \mathrm{~kg} \mathrm{ha}^{-1}\right.$ per year) and Northern State (18 $\mathrm{kg} \mathrm{ha}^{-1}$ per year). In Northern State, the yield dropped sharply in the 2007/08 season and was consistently below the trend line until $2016 / 17$ so that additional linear regression analysis for $1970 / 71$ to $2006 / 07$ revealed a remarkable increasing trend ( $45 \mathrm{~kg} \mathrm{ha}^{-1}$ per year) before a decline started in 2007/08 (Fig. 5). The original yields were lower than the counterfactual yields, and the differences increased from the 1970s to the 2010s in all study areas (Fig. 6). In the
Fig. 5 Irrigated wheat yield in the $1970 / 71$ to $2017 / 18$ seasons in Northern State, Gezira State, and Kassala State, Sudan and their anomalies from regression lines. Linear lines (estimated by least squares regression) in the figures are significant increasing trends in the yield. For Northern State, the dashed regression line for 1970/71-2006/07 was used

\section{Regression}
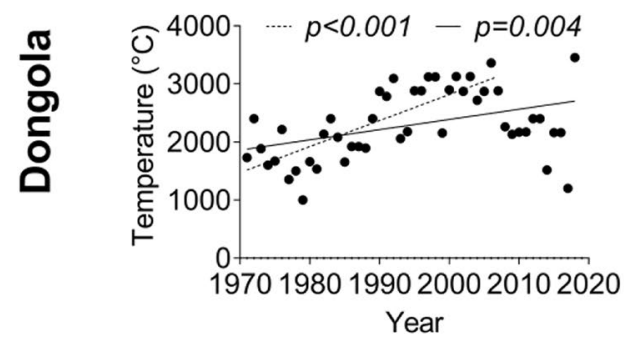

$\overline{1}$
$\frac{\pi}{0}$
$\frac{0}{2}$
$\frac{\pi}{3}$

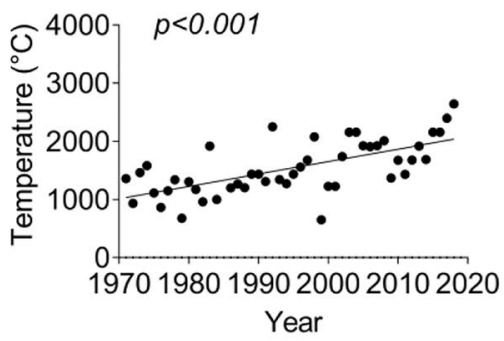

$\frac{\pi}{\frac{\pi}{0}}$

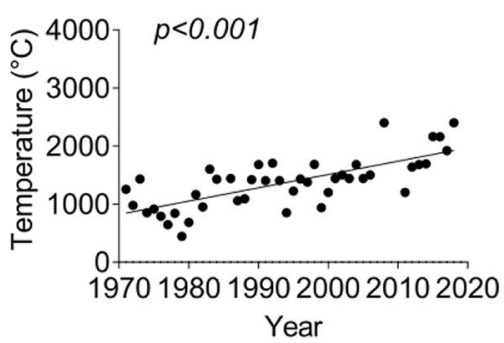

\section{Anomaly}
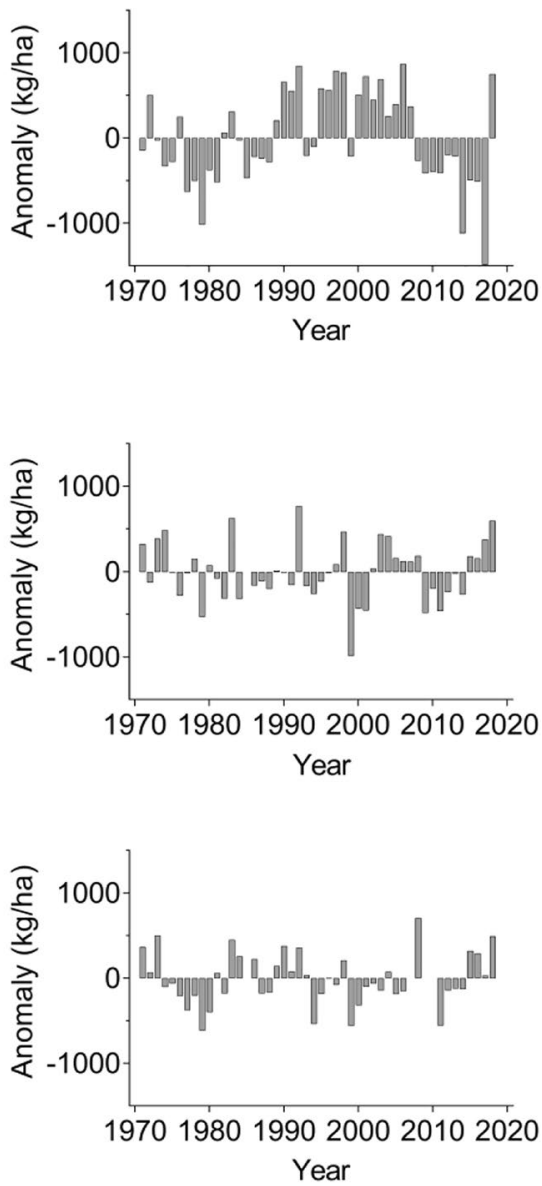


\section{Northern State}

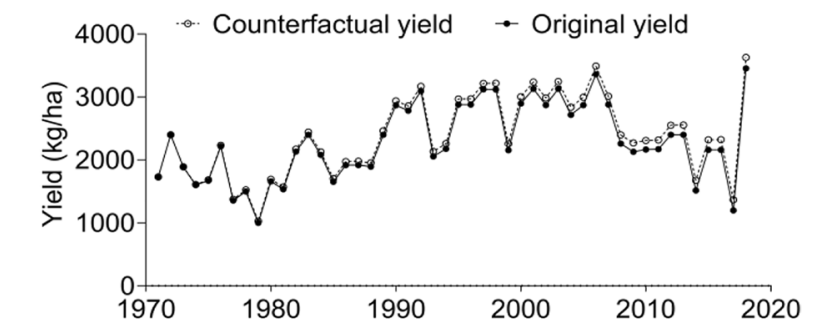

\section{Gezira State}

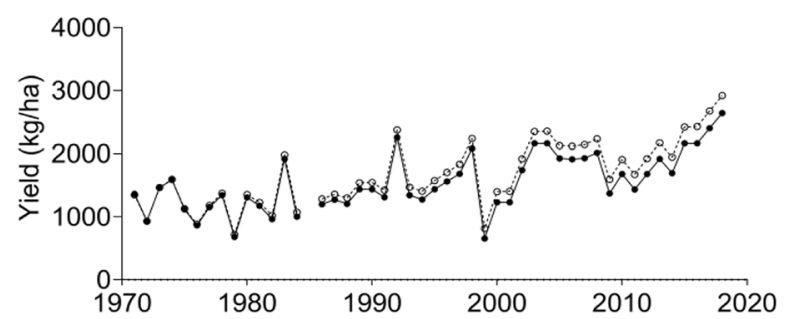

Kassala State

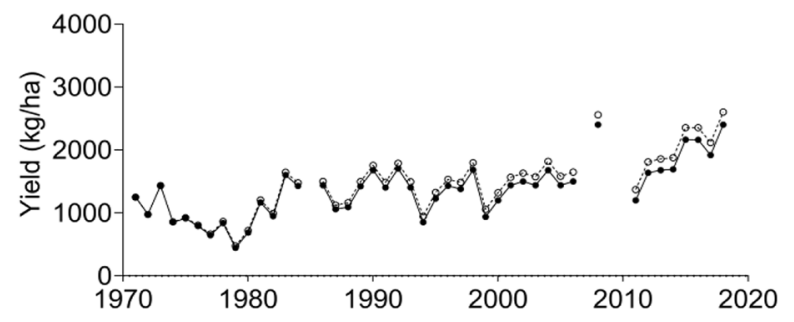

Fig. 6 Time series (1970/71-2017/18 crop seasons) of the original and counterfactual yields of wheat in Northern State, Gezira State, and Kassala State, Sudan. Counterfactual yield was defined as observed yield minus the effect of increasing temperature. The counterfactual yield is the estimated yield what would occur without increasing temperature over the 48 crop seasons

1970s, the original yields were lower than the counterfactual yields on average by $1 \%$ in Northern and Gezira states and by $2 \%$ in Kassala State, and the differences increased in the 2010s (7\%, 12\%, and 9\%, respectively).

Pearson's correlation and Spearman's rank correlation between detrended yields (anomalies in Fig. 5) and the temperature indicators (detrended) are shown in Table 2. In Northern State/Dongola, yield was negatively correlated with November THN and February TMAX (Pearson's correlation) and November THN (Spearman's rank correlation). Additional analysis for the period prior to 2007/08 showed negative correlation of yield with February TMIN $(r=-0.43, \rho=-0.33)$ and THN $(r=-0.43, \rho=-0.61)$, and with November THN $(\rho=-0.41)$, December THN $(\rho=-0.53)$, and January THN $(\rho=-0.63)(p \leq 0.05)$. In Gezira State/Wad Medani, yield was negatively correlated with January TMAX. In Kassala State/New Halfa, yield was negatively correlated with several temperature indicators, particularly with November TMIN and February THN. Better yield-temperature relationships were found with the growing-season temperature indicators (Table 2). In Northern State/Dongola, yield was negatively correlated with the growing-season THN $(r=-0.41, \rho=-0.38)$, and the same result was found for the period prior to 2007/08 ( $r=-0.41$, $\rho=-0.52)$. In Gezira State/Wad Medani, yield was negatively correlated with growing-season TMAX $(r=-0.43$, $\rho=-0.33)$. In Kassala State/New Halfa, yield was negatively correlated with all four indicators, particularly TMIN ( $r=-0.55, \rho=-0.54)$. Relationships of detrended yields with the growing-season TMAX and TMIN are also shown in Fig. 7. In Gezira State/Wad Medani, yield decreased with increased TMAX from $32.6^{\circ} \mathrm{C}$ to $37.1^{\circ} \mathrm{C}(p \leq 0.05)$. In Kassala State/New Halfa, yield was negatively associated with TMAX between $32.7^{\circ} \mathrm{C}$ and $37.2^{\circ} \mathrm{C}$ and TMIN between $14.6{ }^{\circ} \mathrm{C}$ and $19.1{ }^{\circ} \mathrm{C}(p \leq 0.05)$.

\section{Discussion}

The Global Climate Report (NOAA 2020) reveals that 8 of the 10 warmest years at a global scale in the 140 -year record have occurred since 2010; in Africa, the 5 warmest years have occurred since 2015, and the increasing trend in annual temperature since $1981\left(0.31{ }^{\circ} \mathrm{C}\right.$ per decade $)$ has been more than twice that since $1910\left(0.12{ }^{\circ} \mathrm{C}\right.$ per decade $)$. Our study showed increasing trends in annual TMAX and TMIN for the last five decades in three regions in Sudan (Fig. 2). This is in line with the study by Elagib and Mansell (2000), who reported increasing trends in annual mean temperature in Sudan from the 1940 s to the mid-1990s at a rate of $0.12{ }^{\circ} \mathrm{C}$ per decade at Wad Medani and $0.19^{\circ} \mathrm{C}$ per decade at the Kassala meteorological station $\left(15.47^{\circ} \mathrm{N}, 36.40^{\circ} \mathrm{E}, 500 \mathrm{~m}\right)$, which is located in the eastern region about $86 \mathrm{~km}$ east from New Halfa. Our findings are further supported by a study conducted in the Blue Nile-eastern Sudan region (Xu et al. 2010). Elagib and Mansell (2000) have reported no trend in annual mean temperature at Dongola, but we found temperature trends increasing at high rates, particularly annual TMIN, indicating that the warming progresses in the northern region of the country. Increasing temperature trends have been reported from neighboring countries. The east and south parts of the Upper Blue Nile River Basin in northwestern Ethiopia, which is adjacent to the eastern region of Sudan, had rising trends in both annual TMIN and TMAX in 1981-2010 at a rate of between 0.1 and $0.15^{\circ} \mathrm{C}$ per decade (Mengistu et al. 2014). In East Africa (Kenya, Uganda, and Tanzania), annual temperature increased by $1.5^{\circ} \mathrm{C}$ during 1951-2010 (Ongoma and Chen 2017). The highest daily TMAX (close to $50{ }^{\circ} \mathrm{C}$ ) and TMIN $\left(35^{\circ} \mathrm{C}\right.$ ) at Dongola and the highest daily TMIN $\left(>32^{\circ} \mathrm{C}\right)$ at Wad Medani and New Halfa were recorded after 2008. These recorded extremes 
Table 2 Pearson correlation and Spearman's rank correlation between wheat yield anomalies in Northern State, Gezira State, and Kassala State and temperature indicators at the respective meteorological stations (Dongola, Wad Medani, and New Halfa)

\begin{tabular}{|c|c|c|c|c|c|c|c|c|c|c|c|}
\hline \multirow[t]{2}{*}{ Production area/station } & \multirow{2}{*}{$\begin{array}{l}\text { Tempera- } \\
\text { ture indica- } \\
\text { tor }\end{array}$} & \multicolumn{2}{|c|}{ November } & \multicolumn{2}{|c|}{ December } & \multicolumn{2}{|l|}{ January } & \multicolumn{2}{|c|}{ February } & \multicolumn{2}{|l|}{ Season } \\
\hline & & $r$ & $\rho$ & $r$ & $\rho$ & $r$ & $\rho$ & $r$ & $\rho$ & $r$ & $\rho$ \\
\hline \multirow[t]{4}{*}{ Northern State/Dongola } & TMAX & $\begin{array}{l}-0.05 \\
\mathrm{~ns}\end{array}$ & $\begin{array}{l}-0.05 \\
\mathrm{~ns}\end{array}$ & $\begin{array}{l}-0.19 \\
\mathrm{~ns}\end{array}$ & $\begin{array}{l}-0.25 \\
\mathrm{~ns}\end{array}$ & $\begin{array}{l}-0.10 \\
\mathrm{~ns}\end{array}$ & $\begin{array}{l}-0.07 \\
\mathrm{~ns}\end{array}$ & $\begin{array}{l}-0.32 \\
*\end{array}$ & $\begin{array}{l}-0.22 \\
\mathrm{~ns}\end{array}$ & $\begin{array}{l}-0.26 \\
\mathrm{~ns}\end{array}$ & $\begin{array}{l}-0.26 \\
\mathrm{~ns}\end{array}$ \\
\hline & TMIN & $\begin{array}{l}-0.19 \\
\mathrm{~ns}\end{array}$ & $\begin{array}{l}-0.13 \\
\mathrm{~ns}\end{array}$ & $\begin{array}{l}-0.04 \\
\mathrm{~ns}\end{array}$ & $\begin{array}{l}-0.13 \\
\mathrm{~ns}\end{array}$ & $\begin{array}{l}-0.07 \\
\mathrm{~ns}\end{array}$ & $\begin{array}{l}-0.04 \\
\mathrm{~ns}\end{array}$ & $\begin{array}{l}-0.19 \\
\mathrm{~ns}\end{array}$ & $\begin{array}{l}-0.21 \\
\mathrm{~ns}\end{array}$ & $\begin{array}{l}-0.17 \\
\mathrm{~ns}\end{array}$ & $\begin{array}{l}-0.21 \\
\mathrm{~ns}\end{array}$ \\
\hline & THD & $\begin{array}{l}-0.251 \\
\mathrm{~ns}\end{array}$ & $\begin{array}{l}-0.24 \\
\mathrm{~ns}\end{array}$ & $\begin{array}{l}0.10 \\
\text { ns }\end{array}$ & $\begin{array}{l}-0.04 \\
\mathrm{~ns}\end{array}$ & $\begin{array}{l}-0.16 \\
\mathrm{~ns}\end{array}$ & $\begin{array}{l}-0.08 \\
\mathrm{~ns}\end{array}$ & $\begin{array}{l}-0.11 \\
\mathrm{~ns}\end{array}$ & $\begin{array}{l}-0.20 \\
\mathrm{~ns}\end{array}$ & $\begin{array}{l}-0.22 \\
\mathrm{~ns}\end{array}$ & $\begin{array}{l}-0.32 \\
*\end{array}$ \\
\hline & THN & $\begin{array}{l}-0.38 \\
*\end{array}$ & $\begin{array}{l}-0.33 \\
*\end{array}$ & $\begin{array}{l}-0.06 \\
\mathrm{~ns}\end{array}$ & $\begin{array}{l}-0.04 \\
\mathrm{~ns}\end{array}$ & $\begin{array}{l}-0.11 \\
\mathrm{~ns}\end{array}$ & $\begin{array}{l}-0.07 \\
\mathrm{~ns}\end{array}$ & $\begin{array}{l}-0.05 \\
\mathrm{~ns}\end{array}$ & $\begin{array}{l}-0.15 \\
\mathrm{~ns}\end{array}$ & $\begin{array}{l}-0.41 \\
* *\end{array}$ & $\begin{array}{l}-0.38 \\
* *\end{array}$ \\
\hline \multirow[t]{4}{*}{ Gezira State/Wad Medani } & TMAX & $\begin{array}{l}-0.23 \\
\mathrm{~ns}\end{array}$ & $\begin{array}{l}-0.17 \\
\mathrm{~ns}\end{array}$ & $\begin{array}{l}-0.18 \\
\mathrm{~ns}\end{array}$ & $\begin{array}{l}-0.15 \\
\mathrm{~ns}\end{array}$ & $\begin{array}{l}-0.38 \\
* *\end{array}$ & $\begin{array}{l}-0.36 \\
*\end{array}$ & $\begin{array}{l}-0.28 \\
\mathrm{~ns}\end{array}$ & $\begin{array}{l}-0.16 \\
\mathrm{~ns}\end{array}$ & $\begin{array}{l}-0.43 \\
* *\end{array}$ & $\begin{array}{l}-0.33 \\
*\end{array}$ \\
\hline & TMIN & $\begin{array}{l}-0.11 \\
\mathrm{~ns}\end{array}$ & $\begin{array}{l}-0.10 \\
\mathrm{~ns}\end{array}$ & $\begin{array}{l}-0.19 \\
\mathrm{~ns}\end{array}$ & $\begin{array}{l}-0.10 \\
\mathrm{~ns}\end{array}$ & $\begin{array}{l}-0.28 \\
\mathrm{~ns}\end{array}$ & $\begin{array}{l}-0.26 \\
\mathrm{~ns}\end{array}$ & $\begin{array}{l}0.18 \\
\mathrm{~ns}\end{array}$ & $\begin{array}{l}-0.10 \\
\mathrm{~ns}\end{array}$ & $\begin{array}{l}-0.15 \\
\mathrm{~ns}\end{array}$ & $\begin{array}{l}-0.17 \\
\mathrm{~ns}\end{array}$ \\
\hline & THD & $\begin{array}{l}-0.16 \\
\mathrm{~ns}\end{array}$ & $\begin{array}{l}-0.21 \\
\mathrm{~ns}\end{array}$ & $\begin{array}{l}-0.19 \\
\mathrm{~ns}\end{array}$ & $\begin{array}{l}-0.18 \\
\mathrm{~ns}\end{array}$ & $\begin{array}{l}0.09 \\
\text { ns }\end{array}$ & $\begin{array}{l}0.12 \\
\mathrm{~ns}\end{array}$ & $\begin{array}{l}0.10 \\
\text { ns }\end{array}$ & $\begin{array}{l}0.11 \\
\mathrm{~ns}\end{array}$ & $\begin{array}{l}-0.31 \\
*\end{array}$ & $\begin{array}{l}-0.19 \\
\mathrm{~ns}\end{array}$ \\
\hline & THN & $\begin{array}{l}-0.06 \\
\mathrm{~ns}\end{array}$ & $\begin{array}{l}-0.03 \\
\mathrm{~ns}\end{array}$ & $\begin{array}{l}0.07 \\
\mathrm{~ns}\end{array}$ & $\begin{array}{l}0.05 \\
\mathrm{~ns}\end{array}$ & $\begin{array}{l}-0.04 \\
\mathrm{~ns}\end{array}$ & $\begin{array}{l}-0.05 \\
\mathrm{~ns}\end{array}$ & $\begin{array}{l}-0.09 \\
\mathrm{~ns}\end{array}$ & $\begin{array}{l}-0.14 \\
\mathrm{~ns}\end{array}$ & $\begin{array}{l}-0.10 \\
\mathrm{~ns}\end{array}$ & $\begin{array}{l}-0.09 \\
\mathrm{~ns}\end{array}$ \\
\hline \multirow[t]{4}{*}{ Kassala State/New Halfa } & TMAX & $\begin{array}{l}-0.32 \\
*\end{array}$ & $\begin{array}{l}-0.28 \\
\mathrm{~ns}\end{array}$ & $\begin{array}{l}-0.23 \\
\mathrm{~ns}\end{array}$ & $\begin{array}{l}-0.19 \\
\mathrm{~ns}\end{array}$ & $\begin{array}{l}-0.41 \\
* *\end{array}$ & $\begin{array}{l}-0.39 \\
* *\end{array}$ & $\begin{array}{l}-0.23 \\
\mathrm{~ns}\end{array}$ & $\begin{array}{l}-0.19 \\
\mathrm{~ns}\end{array}$ & $\begin{array}{l}-0.42 \\
* *\end{array}$ & $\begin{array}{l}-0.26 \\
\mathrm{~ns}\end{array}$ \\
\hline & TMIN & $\begin{array}{l}-0.42 \\
* *\end{array}$ & $\begin{array}{l}-0.54 \\
* *\end{array}$ & $\begin{array}{l}-0.27 \\
\mathrm{~ns}\end{array}$ & $\begin{array}{l}-0.26 \\
\mathrm{~ns}\end{array}$ & $\begin{array}{l}-0.37 \\
*\end{array}$ & $\begin{array}{l}-0.37 \\
*\end{array}$ & $\begin{array}{l}-0.26 \\
\mathrm{~ns}\end{array}$ & $\begin{array}{l}-0.23 \\
\mathrm{~ns}\end{array}$ & $\begin{array}{l}-0.55 \\
* *\end{array}$ & $\begin{array}{l}-0.54 \\
* *\end{array}$ \\
\hline & THD & $\begin{array}{l}-0.24 \\
\mathrm{~ns}\end{array}$ & $\begin{array}{l}-0.31 \\
*\end{array}$ & $\begin{array}{l}-0.18 \\
\mathrm{~ns}\end{array}$ & $\begin{array}{l}-0.15 \\
\mathrm{~ns}\end{array}$ & $\begin{array}{l}-0.35 \\
*\end{array}$ & $\begin{array}{l}-0.31 \\
*\end{array}$ & $\begin{array}{l}-0.22 \\
\mathrm{~ns}\end{array}$ & $\begin{array}{l}-0.22 \\
\mathrm{~ns}\end{array}$ & $\begin{array}{l}-0.42 \\
* *\end{array}$ & $\begin{array}{l}-0.30 \\
\mathrm{~ns}\end{array}$ \\
\hline & THN & $\begin{array}{l}-0.32 \\
*\end{array}$ & $\begin{array}{l}-0.41 \\
* *\end{array}$ & $\begin{array}{l}-0.10 \\
\mathrm{~ns}\end{array}$ & $\begin{array}{l}-0.13 \\
\mathrm{~ns}\end{array}$ & $\begin{array}{l}-0.04 \\
\mathrm{~ns}\end{array}$ & $\begin{array}{l}-0.22 \\
\mathrm{~ns}\end{array}$ & $\begin{array}{l}-0.46 \\
* *\end{array}$ & $\begin{array}{l}-0.41 \\
* *\end{array}$ & $\begin{array}{l}-0.41 \\
* *\end{array}$ & $\begin{array}{l}-0.51 \\
* *\end{array}$ \\
\hline
\end{tabular}

TMAX, maximum temperature; TMIN, minimum temperature; THD, proportion of hot days in a month; THN, proportion of hot nights in a month; $r$, Pearson's correlation coefficient; $\rho$, Spearman's rank correlation coefficient; ${ }^{*} p \leq 0.05 ;{ }^{* *} p \leq 0.01 ; n s$, not significant

also indicate that the study areas have been experiencing rapid warming in the last decade.

In the study areas, high temperatures occur late in the hot season (March-May) or early in the wet season (June-October), and therefore, wheat is grown under cooler temperature in the dry season (Fig. 3). Elagib (2010) has reported that the dry-season TMIN increased at a rate of $0.185^{\circ} \mathrm{C}$ per decade at Wad Medani from the 1940s to the mid-2000s, but found no trend in TMAX, whereas we found no trend in TMIN but an increasing trend in TMAX (Fig. 4). The trend rate of TMIN at New Halfa was, by and large, consistent with the previously reported rate at the Kassala meteorological station $\left(0.357^{\circ} \mathrm{C}\right.$ per decade). For Dongola, we found increasing trends in both TMAX and TMIN, and the TMIN rate was more than double the TMAX rate, implying that rapid warming is occurring in the nighttime during the growing season. In contrast, Elagib (2010) reported no increasing trend in dry-season (October-March) TMAX or TMIN at Dongola and even a decreasing trend in TMAX $\left(-0.166^{\circ} \mathrm{C}\right.$ per decade). This difference might be attributed to a difference in the data analysis between the studies, i.e., different study periods.
The increasing trend rate of yield was around $20 \mathrm{~kg} \mathrm{ha}^{-1}$ per year (Fig. 5). This confirms the long-term improvement of spring wheat cultivars, which efficiently respond to nitrogen fertilizer, since 1960 (Tahir et al. 2020b). Meanwhile, the difference between the original and counterfactual yields was increasing (Fig. 6) with increasing temperature (Fig. 4). To avoid the confounding influence of increasing yield and temperature trends, we used the data detrending approach to analyze the relationship between yield and temperature variations. Consistent with previous reports (e.g., Asseng et al. 2017; Morgounov et al. 2018), we found negative relationships of wheat yields with TMAX and TMIN during the growing season (Table 2; Fig. 7). Loss of pollen viability and shortened grain-filling period decrease grain number and weight, and hence yield (Ishag and Mohamed 1996; Prasad et al. 2008; Nuttall et al. 2018). The best indicator of the growing-season temperature for yield was THN in Northern State/Dongola and TMAX in Gezira State/Wad Medani, whereas all four indicators were significant in Kassala State/New Halfa. These findings imply that THN in northern areas, TMAX in central areas, and all four indicators in eastern areas can be used to detect the effect of 
Fig. 7 Relationships between wheat yield anomalies and growing-season (November-February) average daily maximum (TMAX) and minimum temperatures (TMIN) for Northern State/Dongola, Gezira State/Wad Medani, and Kassala State/New Halfa, Sudan. Linear lines (estimated by least squares regression) in the figures are significant yield-temperature relationships

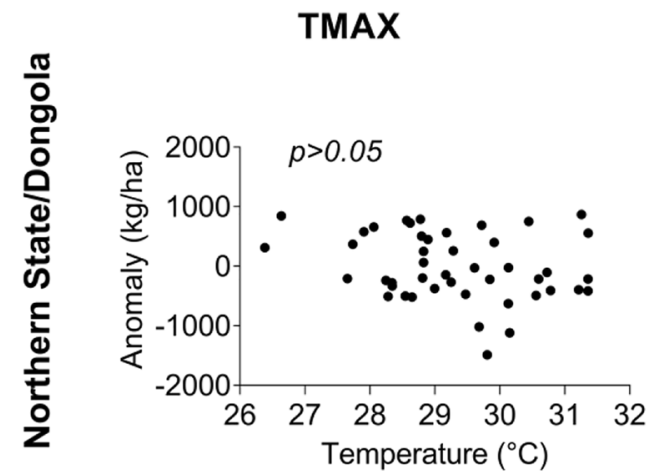

TMIN

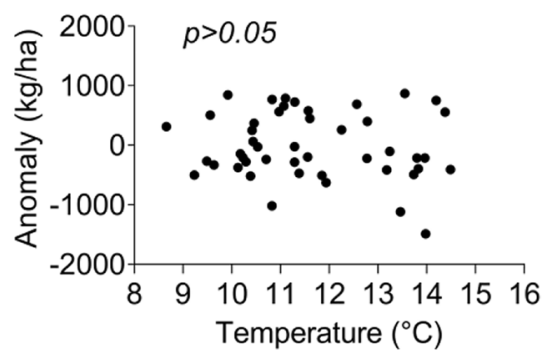

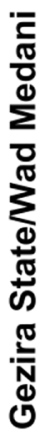
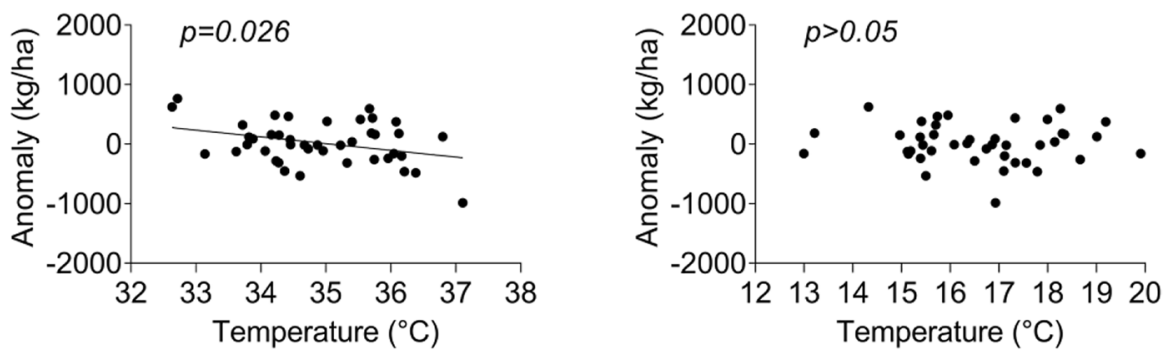

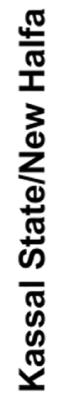

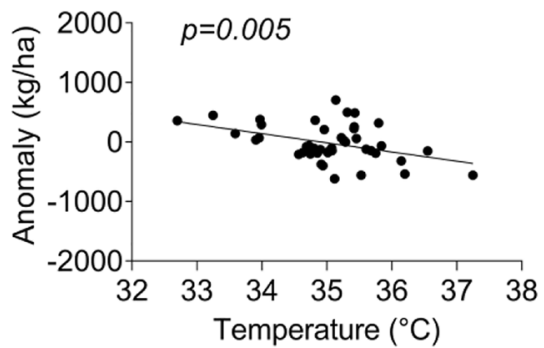

high temperature on wheat production. Asseng et al. (2017) reported a negative relationship between yield and mean growing-season temperature in hot environments where spring wheat is grown under irrigated conditions, e.g., in northern India. Such relationships have also been reported for rainfed spring wheat in cool and warm regions in Canada, the USA, Russia, and Kazakhstan (Morgounov et al. 2018). A model simulation study by Lobell et al. (2005) showed the association of increasing yield with decreasing TMIN during 1988-2002 in irrigated wheat production regions of northeast Mexico.

High daytime temperature $\left(\geq 35{ }^{\circ} \mathrm{C}\right)$ during anthesis decreases seed set and grain number (Narayanan et al. 2015; Nuttall et al. 2018). In the central and eastern regions of Sudan, wheat flowers mostly in January, which could partially explain the negative relationship between yield and January TMAX in Gezira State/Wad Medani and Kassala State/New Halfa (Table 2). In crop modeling, the negative effect of daily TMAX on wheat yield is demonstrated by setting an upper temperature limit (e.g., $34{ }^{\circ} \mathrm{C}$ in APSIM) for calculating a heat-stress factor (Asseng et al. 2011). Here, $35^{\circ} \mathrm{C}$ was set as the threshold temperature to calculate THD, but no specific monthly THD had a negative effect on yield, although Kassala State/New Halfa had a weak correlation of yield with November THD. The optimum temperature for wheat is around $20^{\circ} \mathrm{C}$ (Porter and Gawith 1999); therefore, daily TMIN should be below $20^{\circ} \mathrm{C}$. In this study, $20^{\circ} \mathrm{C}$ was set as the threshold to calculate THN. Monthly minimum temperature indicators (THN and TMIN) in January and February (heading, flowering, and ripening period in central and eastern Sudan) had a negative effect on yield in Kassala State/New Halfa (Table 2). This is in line with the negative effect of the nighttime temperature $\geq 20{ }^{\circ} \mathrm{C}$ during grain filling on wheat grain number per spike and size (Prasad et al. 2008), and during anthesis on grain number and grain yield (Narayanan et al. 2015). In crop modeling, both the upper 
limit for daily TMAX and that for daily TMIN can be crucial for simulating the effect of high temperature on wheat yield in Sudan.

Crop yield can be influenced by government policies such as socioeconomic transformation of agricultural industry (e.g., Hlavinka et al. 2009) and economic liberalization (e.g., Al-Feel and Al-Basheer 2012). In Northern State, the sharp dropped yield in the 2007/08 season (Fig. 5) might have happened because the government stopped support for agricultural inputs in wheat production in the mid-2000s, and accordingly the farmers might have minimized the use of the inputs such as fertilizers. The government has provided large-scale public irrigation schemes (e.g., the Gezira Scheme) with irrigation facilities, fertilizers, pesticides, and improved seeds, but such services are not available for small-scale irrigation schemes scattered along the Nile River in Northern State (Elsheikh et al. 2015). The amount of irrigation water applied to the crop field may be another explanatory factor that can be considered for the yield-temperature relationship in Sudan; for example, the yield of wheat in the Gezira Scheme is correlated with total irrigation water supply from the Sennar Dam (Al Zayed et al. 2015). However, detailed information on irrigation water allocation to wheat is not available; hence, the relationship with the yield remains unknown in this study. Therefore, future study is needed to clarify whether the irrigation information is a key to the yield-temperature relationship analysis.

\section{Conclusions}

The yield-temperature relationship analysis is needed for understanding wheat production in hot environments under changing climate. Using trend analyses of temperature indicators and wheat yields, we showed upward trends in both the annual and growing-season temperatures. In particular, nighttime temperature in the northern region (Dongola) is rapidly raising. The yields are negatively associated with both daytime and nighttime temperature indicators during the growing season, and the negative effect of raising temperature on yield has increased in recent years. Specifically, the yield deviation is associated with THN in the northern region, TMAX and THD in the central region, and TMAX, TMIN, THD, and THN in the eastern region. In the central and eastern regions, the temperature indicators in January (during the heading to flowering period) contribute the most to the yield deviation. Thus, Sudan is likely warming, which will adversely affect the country's breadbasket in coming decades.

Acknowledgements We are grateful to the Ministry of Agriculture and Natural Resources and the Sudan Meteorological Authority for providing the data. This study was funded by the Science and Technology
Research Partnership for Sustainable Development, Japan Science and Technology Agency/Japan International Cooperation Agency (JPMJSA1805) and the Joint Research Program of the Arid Land Research Center, Tottori University (No. 30F2001).

Author contribution Conceptualization: Abuelgasim I.I. Musa, Mitsuru Tsubo, Imad-Eldin A. Ali-Babiker. Methodology: Abuelgasim I.I. Musa, Mitsuru Tsubo, Imad-Eldin A. Ali-Babiker, Toshichika Iizumi. Formal analysis and investigation: Abuelgasim I.I. Musa. Writingoriginal draft preparation: Abuelgasim I.I. Musa. Writing-review and editing: Mitsuru Tsubo, Imad-Eldin A. Ali-Babiker, Toshichika Iizumi, Yasunori Kurosaki, Yasuomi Ibaraki, Faisal M.A. El-Hag, Izzat S.A. Tahir, Hisashi Tsujimoto.

Funding This study was funded by the Science and Technology Research Partnership for Sustainable Development, Japan Science and Technology Agency/Japan International Cooperation Agency (JPMJSA1805) and the Joint Research Program of the Arid Land Research Center, Tottori University (No. 30F2001).

Data availability All the data used for this study are available and provided by the public entities (the Ministry of Agriculture and Natural Resources of Sudan and the Sudan Meteorological Authority).

Code availability Not applicable.

\section{Declarations}

Ethics approval Not applicable.

Consent to participate Not applicable.

Consent for publication Not applicable.

Conflict of interest The authors declare no competing interests.

Open Access This article is licensed under a Creative Commons Attribution 4.0 International License, which permits use, sharing, adaptation, distribution and reproduction in any medium or format, as long as you give appropriate credit to the original author(s) and the source, provide a link to the Creative Commons licence, and indicate if changes were made. The images or other third party material in this article are included in the article's Creative Commons licence, unless indicated otherwise in a credit line to the material. If material is not included in the article's Creative Commons licence and your intended use is not permitted by statutory regulation or exceeds the permitted use, you will need to obtain permission directly from the copyright holder. To view a copy of this licence, visit http://creativecommons.org/licenses/by/4.0/.

\section{References}

Adam HS, Ageeb OOA (1994) Temperature analysis and wheat yields in the Gezira scheme. In: Saunders DA, Hettel GP (eds) Wheat in heat-stressed environments: irrigated, dry areas and rice-wheat farming systems. CIMMYT, Mexico, pp 143-145

Al Zayed IS, Elagib NA, Ribbe L, Heinrich J (2015) Spatio-temporal performance of large-scale Gezira Irrigation Scheme, Sudan. Agric Syst 133:131-142

Al-Feel MA, Al-Basheer AAR (2012) Economic efficiency of wheat production in Gezira scheme, Sudan. J Saudi Soc Agric Sci 11:1-5 
Asseng S, Foster IAN, Turner NC (2011) The impact of temperature variability on wheat yields. Glob Chang Biol 17:997-1012

Asseng S, Ewert F, Martre P, Rötter RP, Lobell DB, Cammarano D, Kimball BA, Ottman MJ, Wall GW, White JW, Reynolds MP, Alderman PD, Prasad PVV, Aggarwal PK, Anothai J, Basso B, Biernath C, Challinor AJ, De Sanctis G, Doltra J, Fereres E, Garcia-Vila M, Gayler S, Hoogenboom G, Hunt LA, Izaurralde RC, Jabloun M, Jones CD, Kersebaum KC, Koehler A-K, Müller C, Naresh Kumar S, Nendel C, O'Leary G, Olesen JE, Palosuo T, Priesack E, Eyshi Rezaei E, Ruane AC, Semenov MA, Shcherbak I, Stöckle C, Stratonovitch P, Streck T, Supit I, Tao F, Thorburn PJ, Waha K, Wang E, Wallach D, Wolf J, Zhao Z, Zhu Y (2015) Rising temperatures reduce global wheat production. Nat Clim Chang 5:143

Asseng S, Cammarano D, Basso B et al (2017) Hot spots of wheat yield decline with rising temperatures. Glob Chang Biol 23:2464-2472

Brisson N, Gate P, Gouache D, Charmet G, Oury F-X, Huard F (2010) Why are wheat yields stagnating in Europe? A comprehensive data analysis for France. Field Crops Res 119:201-212

Calzadilla A, Rehdanz K, Betts R et al (2013) Climate change impacts on global agriculture. Clim Change 120:357-374

Collins DA, Della-Marta PM, Plummer N, Trewin BC (2000) Trends in annual frequencies of extreme temperature events in Australia. Aust Meteorol Mag 49:277-292

Elagib NA (2010) Trends in intra-and inter-annual temperature variabilities across Sudan. Ambio 39:413-429

Elagib NA, Mansell MG (2000) Recent trends and anomalies in mean seasonal and annual temperatures over Sudan. J Arid Environ 45:263-288

Elsheikh OE, Elbushra AA, Salih AAA (2015) Economic impacts of changes in wheat's import tariff on Sudanese economy. J Saudi Soc Agric Sci 14:68-75

Faki HHM, Ismail MA (1994) Some indicators for wheat production prospects in Sudan. In: Saunders DA, Hettel GP (eds), Wheat in heat-stressed environments: irrigated, dry areas and rice-wheat farming systems. CIMMYT, Mexico, pp 96-104

FAO (2012) Harmonized World Soil Database (version 1.2). Food Agriculture Organization, Rome, Italy and IIASA, Laxenburg, Austria

FAO (2019) FAO crop and food supply assessment mission to the Sudan - special report. Rome

García GA, Dreccer MF, Miralles DJ, Serrago RA (2015) High night temperatures during grain number determination reduce wheat and barley grain yield: a field study. Glob Chang Biol 21:4153-4164

García GA, Serrago RA, Dreccer MF, Miralles DJ (2016) Post-anthesis warm nights reduce grain weight in field-grown wheat and barley. Field Crops Res 195:50-59

Gebrechorkos SH, Hülsmann S, Bernhofer C (2019) Changes in temperature and precipitation extremes in Ethiopia, Kenya, and Tanzania. Int J Climatol 39:18-30

Gil-Alana LA, Yaya OS, Fagbamigbe AF (2019) Time series analysis of quarterly rainfall and temperature (1900-2012) in sub Saharan African countries. Theor Appl Climatol 137:61-76

Hatfield JL, Prueger JH (2015) Temperature extremes: effect on plant growth and development. Weather Clim Extrem 10:4-10

Hatfield JL, Boote KJ, Kimball BA, Ziska LH, Izaurralde RC, Ort D, Thomson AM, Wolfe DW (2011) Climate impacts on agriculture: implications for crop production. Agron J 103:351-370

Hlavinka P, Trnka M, Semerádová D, Dubrovský M, Žalud Z, Možný M (2009) Effect of drought on yield variability of key crops in Czech Republic. Agric for Meteorol 149:431-442

Iizumi T, Shiogama H, Imada Y, Hanasaki N, Takikawa H, Nishimori M (2018) Crop production losses associated with anthropogenic climate change for 1981-2010 compared with preindustrial levels. Int J Climatol 38:5405-5417
IPCC (2014) Climate change 2014: impacts, adaptation, and vulnerability. Part A: global and sectoral aspects. Contribution of working group II to the fifth assessment report of the intergovernmental panel on climate change [Field CB, Barros VR, Dokken DJ, Mach KJ, Mastrandrea MD, Bilir TE, Chatterjee M, Ebi KL, Estrada YO, Genova RC, Girma B, Kissel ES, Levy AN, MacCracken S, Mastrandrea PR, White LL (eds.)]. Cambridge University Press, Cambridge

IPCC (2019) Climate change and land: an IPCC special report on climate change, desertification, land degradation, sustainable land management, food security, and greenhouse gas fluxes in terrestrial ecosystems [Shukla PR, Skea J, Calvo Buendia E, MassonDelmotte V, Pörtner H-O, Roberts DC, Zhai P, Slade R, Connors S, van Diemen R, Ferrat M, Haughey E, Luz S, Neogi S, Pathak M, Petzold J, Portugal Pereira J, Vyas P, Huntley E, Kissick K, Belkacemi M, Malley J (eds)]

Ishag HM, Mohamed BA (1996) Phasic development of spring wheat and stability of yield and its components in hot environments. Field Crops Res 46:169-176

Licker R, Kucharik CJ, Doré T, Lindeman MJ, Makowski D (2013) Climatic impacts on winter wheat yields in Picardy, France and Rostov, Russia: 1973-2010. Agric for Meteorol 176:25-37

Lobell DB, Field CB (2007) Global scale climate-crop yield relationships and the impacts of recent warming. Environ Res Lett 2:014002

Lobell DB, Ortiz-Monasterio JI, Asner GP, Matson PA, Naylor RL, Falcon WP (2005) Analysis of wheat yield and climatic trends in Mexico. Field Crops Res 94:250-256

Lobell DB, Schlenker W, Costa-Roberts J (2011) Climate trends and global crop production since 1980. Science 333:616-620

Mengistu D, Bewket W, Lal R (2014) Recent spatiotemporal temperature and rainfall variability and trends over the Upper Blue Nile River Basin, Ethiopia. Int J Climatol 34:2278-2292

Moore FC, Lobell DB (2015) Climate fingerprint on European crop yields. Proc Natl Acad Sci USA 112:2670-2675

Morgounov A, Sonder K, Abugalieva A, Bhadauria V, Cuthbert RD, Shamanin V, Zelenskiy Y, DePauw RM (2018) Effect of climate change on spring wheat yields in North America and Eurasia in 1981-2015 and implications for breeding. PLoS One 13:e0204932

Narayanan S, Prasad PVV, Fritz AK, Boyle DL, Gill BS (2015) Impact of high night-time and high daytime temperature stress on winter wheat. J Agron Crop Sci 201:206-218

Negassa A, Shiferaw B, Koo J et al (2013) The potential for wheat production in Africa: analysis of biophysical suitability and economic profitability. CIMMYT, Mexico

Nicholls N (1997) Increased Australian wheat yield due to recent climate trends. Nature 387:484-485

NOAA National Centers for Environmental Information (2020) State of the climate: global climate report - annual 2019. https://www. ncdc.noaa.gov/sotc/global/201913. Accessed 14 Sept 2020

Nsubuga FW, Olwoch JM, Rautenbach H (2014) Variability properties of daily and monthly observed near-surface temperatures in Uganda: 1960-2008. Int J Climatol 34:303-314

Nuttall JG, Barlow KM, Delahunty AJ, Christy BP, O'Leary GJ (2018) Acute high temperature response in wheat. Agron J 110:1296-1308

Omondi PA, Awange JL, Forootan E, Ogallo LA, Barakiza R, Girmaw GB, Fesseha I, Kululetera V, Kilembe C, Mbati MM, Kilavi M, King'uyu SM, Omeny PA, Njogu A, Badr EM, Musa TA, Muchiri P, Bamanya D, Komutunga E (2014) Changes in temperature and precipitation extremes over the Greater Horn of Africa region from 1961 to 2010. Int J Climatol 34:1262-1277

Ongoma V, Chen H (2017) Temporal and spatial variability of temperature and precipitation over East Africa from 1951 to 2010. Meteorol Atmos Phys 129:131-144 
Porter JR, Gawith M (1999) Temperatures and the growth and development of wheat: a review. Eur J Agron 10:23-36

Prasad PVV, Pisipati SR, Ristic Z, Bukovnik U, Fritz AK (2008) Impact of nighttime temperature on physiology and growth of spring wheat. Crop Sci 48:2372-2380

Ray DK, West PC, Clark M, Gerber JS, Prishchepov AV, Chatterjee S (2019) Climate change has likely already affected global food production. PLoS One 14(5):e0217148

Tack J, Barkley A, Nalley LL (2015) Effect of warming temperatures on US wheat yields. Proc Natl Acad Sci 112:6931-6936

Tahir ISA, Mustafa HM, Idris AAM, Elhashimi AMA, Hassan MK, Fadul EM, Kurmut AMA, Eltayeb SM, Meheesi S, Hassan AO, Abdalla OS, Assefa S (2020a) Enhancing wheat production and food security in Sudan through scaling up improved technologies using innovation platforms. Int J Agric Sustain 18:376-388

Tahir ISA, Elbashier EME, Ibrahim MAS, Saad ASI, Abdalla OS (2020b) Genetic gain in wheat grain yield and nitrogen use efficiency at different nitrogen levels in an irrigated hot environment. Int J Agronomy 2020:9024671

Tahir ISA, Elahmedi AB, Ibrahim AS, Abdalla OS (2000) Genetic improvement in grain yield and associated changes in traits of bread wheat cultivars in the Sudan. In: The eleventh regional wheat workshop for Eastern, Central and Southern Africa. Addis Ababa, Ethiopia. CIMMYT. pp 60-66
Tahir ISA, Mustafa HM, Saad ASI, Elbashier EME, Elhashimi AMA, Abdeldaim MGA, Hassan MK, Gorafi YSA, Meheesi S, Idris AAM, Ibrahim HA, Eltayeb SM, Hamza FEA, Abdalla OS, Hamada AA, Abuelgassim AMA (2018) Grain yield and stability of elite stem and leaf rusts resistant bread wheat genotypes under the hot environments of Sudan: a proposal for the release of three bread wheat varieties. National variety release committee meeting, 2 April 2018, Khartoum, Sudan

Wang XL, Feng Y (2013) RHtestsV4 user manual. Climate Research Division, Atmospheric Science and Technology Directorate, Science and Technology Branch, Environment Canada. 28p

Xu CY, Zhang Q, El Hag El Tahir M, Zhang Z (2010) Statistical properties of the temperature, relative humidity, and net solar radiation in the Blue Nile-eastern Sudan region. Theor Appl Climatol 101:397-409

You L, Rosegrant MW, Wood S, Sun D (2009) Impact of growing season temperature on wheat productivity in China. Agric for Meteorol 149:1009-1014

Publisher's note Springer Nature remains neutral with regard to jurisdictional claims in published maps and institutional affiliations. 